\title{
Molecular Imaging with
}

\section{$3^{\prime}$-deoxy-3'[(18)F]-Fluorothymidine $\left({ }^{18}\right.$ F-FLT) PET/CT for Early Response to Targeted Therapies in Sarcomas: A Pilot Study}

\author{
Kalevi Kairemo ${ }^{1}$, Elmer B. Santos ${ }^{1}$, Homer A. Macapinlac ${ }^{1}$, Shreyaskumar Patel ${ }^{2}$, \\ Anthony P. Conley ${ }^{2}$, David S. Hong ${ }^{3}$ and Vivek Subbiah ${ }^{3, *(D)}$ \\ 1 Department of Nuclear Medicine, The University of Texas MD Anderson Cancer Center, 1400 Pressler Street, \\ Unit 1483, FCT 16.6005, Houston, TX 77030, USA; Kalevi.Kairemo@gmail.com (K.K.); \\ ebsantos@mdanderson.org (E.B.S.); hmacapinlac@mdanderson.org (H.A.M.) \\ 2 Department of Sarcoma Medical Oncology, Division of Cancer Medicine, The University of Texas, M.D. \\ Anderson Cancer Center, Houston, TX 77030; USA; spatel@mdanderson.org (S.P.); \\ aconley@mdanderson.org (A.P.C.) \\ 3 Department of Investigational Cancer Therapeutics, Division of Cancer Medicine, The University of Texas, \\ M.D. Anderson Cancer Center, Houston, TX 77030, USA; dshong@mdanderson.org \\ * Correspondence: vsubbiah@mdanderson.org
}

Received: 31 January 2020; Accepted: 16 February 2020; Published: 25 February 2020

\begin{abstract}
Although $3^{\prime}$-deoxy-3'[(18)F]-fluorothymidine (FLT)-positron emission tomography (PET) has been utilized for tumor response assessment to neoadjuvant chemotherapy in soft tissue sarcomas, it has not been exploited for the assessment of early response to systematically targeted therapies. Herein, we investigated the ${ }^{18}$ F-FLT PET/CT kinetics in patients with sarcoma who received targeted therapies. Among 15 patients with sarcoma who underwent ${ }^{18} \mathrm{~F}-\mathrm{FLT}$ PET/CT, 5 patients (33\%) patients were imaged at three time points: At baseline and at 1-15 weeks (MDM2-inhibitor treatment), and 10 patients (67\%) were imaged twice: At baseline and at $1-4$ weeks (MDM2 inhibitor, $n=5$; c-met inhibitor $n=5$ ). The patients with sarcoma had a total of 18 identifiable tumors. Twelve of 15 patients $(80 \%)$ demonstrated ${ }^{18} \mathrm{~F}$-FLT concentrations changes early, i.e., at $1-4$ weeks. Eight patients responded $(53.3 \%)$, four patients progressed $(26.7 \%$ ) based on FLT change of more than $10 \%$ increase, and three patients $(20 \%)$ demonstrated no change. ${ }^{18}$ F-FLT PET/CT may be used for early response imaging to molecularly targeted therapies in patients with sarcoma. Further larger studies in specific sarcoma sub-types are warranted.
\end{abstract}

Keywords: 18F-FLT PET/CT; sarcoma; targeted therapy; mdm-2; c-met; ${ }^{18}$ F-FDG PET CT

\section{Introduction}

Tumor proliferation and early response to molecularly targeted therapy can be imaged using $3^{\prime}$-deoxy-3' [(18)F]-fluorothymidine positron emission tomography (18 F-FLT PET/CT) [1-5].

Fluorine-18 fluorothymidine $\left({ }^{18} \mathrm{~F}-\mathrm{FLT}\right)$ is a structural analog of the DNA component, thymidine; however, it is not incorporated into the DNA. It is entrapped in the cell due to phosphorylation by thymidine kinase, a part of the proliferation pathway. Hence, this is trapped in the cell and accumulates in the cell. The advantage of ${ }^{18} \mathrm{~F}-\mathrm{FLT}$ is that, it is a marker of tumor proliferation and its uptake has been shown to be proportional to the DNA synthesis rate and correlative with proliferative index [1].

Therefore, imaging of cellular proliferation has the potential to become an important diagnostic and/or theranostic tool to not only evaluate the tumor growth rates, but also objectively assess potential response to treatment [1]. 
${ }^{18}$ F-Fluorodeoxyglucose positron emission tomography/CT ( ${ }^{18} \mathrm{~F}-\mathrm{FDG}$ PET CT) is an established imaging modality for diagnosis and staging of many types of cancers including various types of sarcomas. In the imaging of bone and soft tissue sarcomas, FDG-PET was reported to be highly sensitive and especially relevant for estimation of individual prognosis. [6,7] ${ }^{18}$ F-FDG PET CT has been used in early response evaluation in patients with Ewing sarcoma to insulin-like growth factor receptor (IGF1R) targeted therapies. However, tumor grading and differentiation from benign versus malignant tumors may be impacted by nonspecific uptake in inflammatory cells and aggressive benign tumors in multiple sarcoma subtypes. Earlier studies of FDG-PET use in sarcoma have demonstrated an overlap between benign tumors and low-grade sarcomas [2,8-10].

Given these limitations, other novel imaging methods are warranted. Interestingly, ${ }^{18}$ F-FLT PET/CT has been utilized to image sarcomas and has the potential to be used for grading and staging of multiple aggressive sarcoma sub-types. In a study of ${ }^{18}$ F-FLT PET/CT in the context of neoadjuvant chemotherapy, ${ }^{18}$ F-FLT uptake, but not ${ }^{18}$ F-FDG uptake correlated significantly with tumor grading [10]. Given this background, it would be appealing to non-invasively image cell proliferation and evaluate intra-tumoral kinetics in response to molecularly targeted therapy in sarcoma. We hypothesized that early response and/or resistance to targeted therapy can be evaluated using FLT-PET CT in patients with sarcoma. We evaluated intra-tumoral kinetics by FLT-PET imaging [11], to c-MET inhibitors and MDM2 inhibitors in patients with multiple types of sarcoma.

\section{Patients and Methods}

This was a single-institution study that was approved by the local institutional review board and was compliant with the Health Insurance Portability and Accountability Act. Written informed consent was obtained from each participant. Fifteen patients with histologically proven sarcomas were enrolled. A baseline ${ }^{18}$ F-FLT PET/CT was obtained before treatment with MDM2 or C-MET inhibitor followed by a second ${ }^{18}$ F-FLT PET/CT approximately 1-15 weeks after treatment in all participants (Tables 1 and 2).

Table 1. The $3^{\prime}$-deoxy-3' $[(18)$ F]-fluorothymidine (FLT)-positron emission tomography (PET) kinetics in a minimum of three time points at $1-15$ weeks in patients with sarcoma treated with mdm-2 inhibitors.

\begin{tabular}{|c|c|c|c|c|c|c|}
\hline Age/Gender & Diagnosis/Site & $\begin{array}{c}\text { Baseline } \\
\text { SUV(FLT) } \\
\text { Size in CT }\end{array}$ & $\begin{array}{c}\text { 1st FU } \\
\text { SUV(FLT) } \\
\text { Size in CT }\end{array}$ & $\begin{array}{c}\text { 2nd FU } \\
\text { SUV(FLT) } \\
\text { Size in CT }\end{array}$ & Remarks & $\begin{array}{c}\text { Outcome } \\
\text { (at 7-8 wk) }\end{array}$ \\
\hline $48 / \mathrm{F}$ & $\begin{array}{l}\text { Malignant } \\
\text { fibrous } \\
\text { histiocytoma } \\
\text { (MFH), RLL } \\
\text { mass }\end{array}$ & $\begin{array}{c}4.1 \\
3.2 \times 2.5\end{array}$ & $\begin{array}{c}3.0 \\
3.5 \times 2.8 \\
2 \text { weeks }\end{array}$ & $\begin{array}{c}7.6 \\
5.0 \times 3.9 \\
8 \text { weeks }\end{array}$ & & $+85 \%$ \\
\hline $60 / \mathrm{M}$ & $\begin{array}{c}\text { Ewing } \\
\text { sarcoma, } \mathrm{R} \\
\text { pelvic mass }\end{array}$ & $\begin{array}{c}3.3 \\
7.9 \times 7.0\end{array}$ & $\begin{array}{c}4.1 \\
7.7 \times 7.1 \\
3 \text { weeks }\end{array}$ & $\begin{array}{c}1.9 \\
8.5 \times 7.1 \\
10 \text { weeks }\end{array}$ & & $-42 \%$ \\
\hline $50 / F$ & $\begin{array}{l}\text { Liposarcoma, } \\
\text { anterior } \\
\text { peritoneal } \\
\text { mass }\end{array}$ & $\begin{array}{c}5.8 \\
2.6 \times 1.8\end{array}$ & $\begin{array}{c}4.2 \\
2.0 \times 1.7 \\
8 \text { weeks }\end{array}$ & $\begin{array}{c}3.5 \\
1.7 \times 7.1 \\
15 \text { weeks }\end{array}$ & $\begin{array}{c}\text { Big tumor } \\
\text { change } \\
3.2 \times \\
4.1 \rightarrow 4.1 \times \\
5.5 \rightarrow 5.2 \times \\
5.6\end{array}$ & $-28 \%$ \\
\hline $32 / \mathrm{M}$ & $\begin{array}{l}\text { GNET, } \\
\text { mesenteric } \\
\operatorname{lnn} \mathrm{R}\end{array}$ & $\begin{array}{c}5.2 \\
2.2 \times 1.9 \\
\mathbf{1 2 . 9}\end{array}$ & $\begin{array}{c}3.9 \\
2.0 \times 2.0 \\
\mathbf{1 5 . 4} \\
7 \text { weeks }\end{array}$ & $\begin{array}{c}2.8 \\
1.9 \times 1.7 \\
\mathbf{1 0 . 6} \\
15 \text { weeks }\end{array}$ & $\begin{array}{c}3.2(1 \text { week }) \\
2.0 \times 1.8(1 \\
\text { week }) \\
\text { FDG }\end{array}$ & $-25 \%+19 \%$ \\
\hline
\end{tabular}


Table 1. Cont.

\begin{tabular}{|c|c|c|c|c|c|c|}
\hline Age/Gender & Diagnosis/Site & $\begin{array}{c}\text { Baseline } \\
\text { SUV(FLT) } \\
\text { Size in CT }\end{array}$ & $\begin{array}{c}\text { 1st FU } \\
\text { SUV(FLT) } \\
\text { Size in CT }\end{array}$ & $\begin{array}{c}\text { 2nd FU } \\
\text { SUV(FLT) } \\
\text { Size in CT }\end{array}$ & Remarks & $\begin{array}{c}\text { Outcome } \\
\text { (at 7-8 wk) }\end{array}$ \\
\hline $32 / \mathrm{M}$ & $\begin{array}{l}\text { GNET, } \\
\text { mesenteric } \\
\operatorname{lnn} \mathrm{L}\end{array}$ & $\begin{array}{c}5.5 \\
2.3 \times 1.1 \\
8.2\end{array}$ & $\begin{array}{c}5.9 \\
2.1 \times 1.4 \\
9.9 \\
7 \text { weeks }\end{array}$ & $\begin{array}{c}4.0 \\
2.0 \times 1.2 \\
8.0 \\
15 \text { weeks }\end{array}$ & $\begin{array}{c}3.4(1 \text { week }) \\
1.9 \times 1.5(1 \\
\text { week }) \\
\text { FDG }\end{array}$ & $\begin{array}{r}+7 \% \\
+21 \%\end{array}$ \\
\hline $49 / \mathrm{F}$ & $\begin{array}{l}\text { Uterine } \\
\text { leiomyosarcoma, } \\
\text { RLL mass }\end{array}$ & $\begin{array}{c}8.8 \\
4.9 \times 3.7\end{array}$ & $\begin{array}{c}10.7 \\
4.9 \times 3.8 \\
2 \text { weeks }\end{array}$ & $\begin{array}{c}11.2 \\
5.2 \times 4.2 \\
8 \text { weeks }\end{array}$ & & $+27 \%$ \\
\hline $49 / \mathrm{F}$ & $\begin{array}{l}\text { Uterine } \\
\text { leiomyosarcoma, } \\
\text { LLL mass }\end{array}$ & $\begin{array}{c}8.0 \\
4.2 \times 3.6\end{array}$ & $\begin{array}{c}7.8 \\
4.2 \times 3.5 \\
2 \text { weeks }\end{array}$ & $\begin{array}{c}7.6 \\
4.6 \times 3.7 \\
8 \text { weeks }\end{array}$ & & $-5 \%$ \\
\hline
\end{tabular}

Bold fonts denote $\mathrm{SUV}_{\max }$ of FDG study.

Table 2. The early FLT PET kinetics at 1-4 weeks in patients with sarcoma treated with c-met and mdm-2 inhibitors.

\begin{tabular}{|c|c|c|c|c|c|}
\hline Age/gender & Diagnosis/Site & $\begin{array}{l}\text { Baseline } \\
\text { SUV(FLT) } \\
\text { Size in CT }\end{array}$ & $\begin{array}{c}\text { 1st FU } \\
\text { SUV(FLT) } \\
\text { Size in CT }\end{array}$ & Remarks & Outcome \\
\hline $42 / \mathrm{F}$ & $\begin{array}{l}\text { Clear cell sarcoma, } \\
\text { Left foot } \\
\text { Subcarinal } \ln n\end{array}$ & $\begin{array}{c}3.0 \\
2.2 \times 1.2\end{array}$ & $\begin{array}{c}2.6 \\
2.3 \times 1.5 \\
1 \text { week }\end{array}$ & & $-13 \%$ \\
\hline $74 / \mathrm{F}$ & $\begin{array}{c}\text { Fibrous tumor, pleura } \\
\text { Lung mass }\end{array}$ & $\begin{array}{c}3.0 \\
2.4 \times 1.9\end{array}$ & $\begin{array}{c}1.7 \\
2.5 \times 2.0 \\
1 \text { week }\end{array}$ & $\begin{array}{l}\text { Fibrous tumor } \\
\quad 3.0 \rightarrow 1.7 \\
\text { No FDG response }\end{array}$ & $-43 \%$ \\
\hline $61 / \mathrm{M}$ & $\begin{array}{l}\text { Cardiac angiosarcoma, } \\
\text { atrium, pericardium }\end{array}$ & $\begin{array}{c}3.3 \\
2.6 \times 1.8\end{array}$ & $\begin{array}{c}3.0 \\
2.0 \times 1.7 \\
4 \text { weeks }\end{array}$ & $\begin{array}{c}\text { Another } \\
\text { pericardium } \\
\text { change } 3.9 \rightarrow 5.9\end{array}$ & $\begin{array}{l}+51 \% \\
-9 \%\end{array}$ \\
\hline $27 / \mathrm{F}$ & $\begin{array}{l}\text { Alveolar soft part } \\
\text { sarcoma, } \\
\text { Retroperitoneal } \\
\text { implant }\end{array}$ & $\begin{array}{c}1.8 \\
1.1 \times 1.0\end{array}$ & $\begin{array}{c}1.6 \\
1.3 \times 1.0 \\
4 \text { weeks }\end{array}$ & & $-11 \%$ \\
\hline $54 / \mathrm{F}$ & $\begin{array}{l}\text { Unclassified high } \\
\text { grade sarcoma, distal } \\
\text { right thigh } \\
\text { musculature }\end{array}$ & 6.2 & $\begin{array}{c}5.7 \\
4 \text { weeks }\end{array}$ & $\begin{array}{l}\text { Not measurable } \\
\text { size on } \mathrm{CT}\end{array}$ & $-9 \%$ \\
\hline $58 / \mathrm{M}$ & $\begin{array}{l}\text { Chondomyxoid } \\
\text { sarcoma }\end{array}$ & $\begin{array}{c}1.1 \\
22.7 \times 17.1\end{array}$ & $\begin{array}{c}1.4 \\
22.6 \times 17.7 \\
1 \text { week }\end{array}$ & & $+27 \%$ \\
\hline $55 / \mathrm{F}$ & $\begin{array}{l}\text { Spindle cell sarcoma, } \\
\text { Peritoneal implant }\end{array}$ & $\begin{array}{c}0.7 \\
1.2 \times 1.0\end{array}$ & $\begin{array}{c}0.6 \\
1.3 \times 1.0 \\
3 \text { weeks }\end{array}$ & & $-15 \%$ \\
\hline $39 / \mathrm{M}$ & $\begin{array}{l}\text { High grade sarcoma, } \\
\text { RLL mass }\end{array}$ & $\begin{array}{c}7.2 \\
4.8 \times 2.7\end{array}$ & $\begin{array}{c}7.5 \\
4.8 \times 2.6 \\
1 \text { week }\end{array}$ & & $+4 \%$ \\
\hline $47 / \mathrm{M}$ & $\begin{array}{l}\text { Myxoid liposarcoma, } \\
\text { upper mediastinum }\end{array}$ & $\begin{array}{c}2.1 \\
7.4 \times 3.8\end{array}$ & $\begin{array}{c}2.3 \\
7.7 \times 4.2 \\
3 \text { weeks }\end{array}$ & & $+10 \%$ \\
\hline $22 / \mathrm{M}$ & $\begin{array}{l}\text { Osteosarcoma, } \\
\text { right hemithorax, } \\
\text { pleura }\end{array}$ & $\begin{array}{c}2.1 \\
3.9 \times 3.6\end{array}$ & $\begin{array}{c}1.6 \\
9.1 \times 3.2 \\
4 \text { weeks }\end{array}$ & & $-24 \%$ \\
\hline
\end{tabular}


The radiosynthesis of ${ }^{18} \mathrm{~F}-\mathrm{FLT}$ was produced according to a method already described [2-4,12]. Briefly, fluorine-18 fluoride was prepared by the ${ }^{18} \mathrm{O}(\mathrm{p}, \mathrm{n}){ }^{18} \mathrm{~F}$ reaction using $>95 \% \mathrm{O}-18$ enriched water as the target material with a titanium window and target holder. The enriched water was bombarded with $17 \mathrm{MeV}$ protons at 30 microamps. At the end of bombardment, the target water was pushed out of the target by helium pressure into the hot cell where the fluorine-18 fluoride was trapped on an anion exchange resin. The ${ }^{18} \mathrm{~F}$ fluoride was then eluted with [2.2.2.] Kryptofix ${ }^{\circledR} /$ potassium carbonate solution and the fluoride was dried by azeotropic distillation with acetonitrile. The ${ }^{18} \mathrm{~F}$ fluoride was then reacted with the $5^{\prime}$-benzoate of $2,3^{\prime}$-anhydrothymine in DMSO at $160{ }^{\circ} \mathrm{C}$ (4); then, after cooling down to $50{ }^{\circ} \mathrm{C}, 1 \% \mathrm{NaOH}(0.35 \mathrm{~mL})$ heated to $50{ }^{\circ} \mathrm{C}, 0.2 \mathrm{M} \mathrm{NaH}_{2} \mathrm{PO}_{4}(0.75 \mathrm{~mL})$, and $1.5 \mathrm{~mL}$ of $8 \% \mathrm{EtOH} / 92 \%$ $0.01 \mathrm{M} \mathrm{NaH}_{2} \mathrm{PO}_{4}$ were added before passing through an alumina cartridge and loaded on a preparative HPLC column. The FLT was purified by high-performance liquid chromatography on an ${ }^{18} \mathrm{C}$ reversed phase column using $8 \%$ ethanol/92\% $0.01 \mathrm{M} \mathrm{NaH}_{2} \mathrm{PO}_{4}$ as the mobile phase. The yield was typically 20-50 $\mathrm{mCi}$, and the specific activity was $1-4 \mathrm{Ci} / \mathrm{mmol}$.

We reviewed the medical records of patients with advanced cancer including sarcoma who had functional FLT/PET imaging as part of their care at MD Anderson. This study was performed in accordance with the guidelines of the MD Anderson Institutional Review Board (IRB). Because this was a retrospective chart review, IRB waived the consent requirements. They were enrolled on c-MET and $\mathrm{mdm}-2$-based trials available in the institution.

After a washout period from progression of standard care therapy, patients were enrolled in the Phase 1 clinical trials with targeted therapies. Patients had baseline scans that included CT of the chest, abdomen, and pelvis, and a bone scan. This was primarily used for an evaluation of response. FLT studies were performed before the initiation of the study drug, and follow-up images were obtained according to the therapy protocol. Patients fasted for $3 \mathrm{~h}$ prior to ${ }^{18} \mathrm{~F}-\mathrm{FLT}$ administration.

PET/CT studies were performed using a Discovery ST8 PET/CT system (GE Healthcare) in combination with the CT component of an 8-MDCT scanner (LightSpeed, GE Healthcare). A single-dose injection of 184-360 MBq (4.96-9.72 mCi) of ${ }^{18} \mathrm{~F}-\mathrm{FLT}$ was administered intravenously. Whole-body PET imaging (WB PET) consisted of 4 or 5 bed positions, $10 \mathrm{~min}$ per bed position approximately $60 \mathrm{~min}$ after radiotracer injection. PET images were reconstructed using standard vendor-provided reconstruction algorithms. The CT component of the study consisted of a helical scan covering the head to the mid-thighs ( $120 \mathrm{kVp}, 300 \mathrm{~mA}, 0.5$-s rotation; table speed, $13.5 \mathrm{~mm}$ /rotation) with no contrast enhancement. Axial CT images were reconstructed with a slice thickness of $3.75 \mathrm{~mm}$. The PET projection data were corrected for random coincidences, scatter, and attenuation. Transaxial images were reconstructed into $128 \times 128$ pixel images with a pixel size of at least $4.5 \mathrm{~mm}$. PET images were reconstructed using standard vendor-provided reconstruction algorithms that incorporate ordered-subset expectation maximization and were corrected for attenuation using data from the CT component of the examination; emission data were corrected for scatter, random events, and dead-time losses as well using the PET/CT scanner's standard algorithms. The dose calibrators (CRC-15R; Capintec) were cross-calibrated with the PET/CT measuring instrument to ensure quantitative accuracy of the PET data. Measurements of uptake and retention in tumors were obtained from the WB PET acquisition and compared to normal tissue.

Regional whole-body reconstructed PET/CT data were stored in the Digital Imaging and Communications in Medicine 3.0, part 10, file format, and transferred to a PET/CT image analysis workstation. Three-dimensional volumes of interest (VOIs) of identifiable primary tumors and metastases and source organs were constructed on the CT images, and their positions verified on the corresponding PET images to include all organ activity. These VOIs were then used for PET image analysis. The identifiable source organs analyzed were the heart, liver, gallbladder, kidneys, urinary bladder, small and large intestines, brain, and whole body. Three-dimensional VOI definitions were used to visually inspect for mis-registration due to motion between sequential scans of the same segment. Residual errors were manually corrected by redefining the VOIs when necessary; this was 
necessary only for the gall bladder and urinary bladder, in the event that gradual accumulation of radioactivity as well as enlargement over the course of the PET scan occurred.

Blinded image interpretation was performed by two experienced nuclear medicine specialists (>15 years of experience each, KK, ES). ${ }^{18} \mathrm{~F}-\mathrm{FLT}$ PET/CT uptake of target lesions was evaluated visually as present or absent. Certainty of the findings was graded on a 3-point scale. Only after the scans were visually interpreted and the final interpretation/score entered for each patient did these specialists determine the maximum SUV for each residual mass/lesion by CT, regardless of whether it was FLT-PET-negative. Percentual FLT changes were calculated as compared to baseline SUV-values, and a change of $>10 \%$ was considered significant (cut-off, see Discussion).

\section{Results}

A total of 15 patients with sarcoma were included in the study. The results are presented in Tables 1 and 2. Five patients were treated with an MDM2 inhibitor. They had a total of seven lesions analyzed with ${ }^{18}$ F-FLT PET CT. The patients had a diagnosis of malignant fibrous histiocytoma, Ewing sarcoma, liposarcoma, Gastro neuroectodermal tumor (GNET), and leiomyosarcoma (Table 1)

The patients underwent FLT scanning at baseline and at least twice after the initiation of therapy. One patient had imaging studies at three time points. The first follow-up study was performed at 2-8 weeks and the second follow up was at $8-15$ weeks. The interval between the investigations was at least six weeks. Three of these five patients responded according to the FLT-change, i.e., at least $10 \%$ decrease in activity (based on early response criteria). The two patients who did not respond had lung metastases unilaterally or bilaterally.

Four patient cases are shown (Figures 1-4). A patient with GNET-tumor was studied at baseline and then subsequently at 1,7 , and 15 weeks with ${ }^{18}$ F-FLT. In addition, the patient also had ${ }^{18}$ F-FDG-PET imaging study at baseline and at 7 and 15 weeks (Figure 1). This patient had two mesenteric lymph node metastases (annotated R (right) and L(left)); with ${ }^{18} \mathrm{~F}-\mathrm{FLT}$, the outcome at seven weeks was $-25 \%(\mathrm{R})$ and $+7 \%(\mathrm{~L})$, whereas ${ }^{18} \mathrm{~F}-\mathrm{FDG}$ did not show any response $(+19 \%(\mathrm{R})$ and $+21 \%(\mathrm{~L}))$. Later, at 15 weeks, the response was clear for ${ }^{18} \mathrm{~F}-\mathrm{FLT}$, with a change of $-38 \%(\mathrm{R})$ and $-38 \%(\mathrm{~L})$, whereas ${ }^{18} \mathrm{~F}-\mathrm{FDG}$ did not show any clear response $(-18 \%(\mathrm{R})$ and $-2 \%(\mathrm{~L}))$. A patient with liposarcoma is shown in Figure 2 demonstrating anterior peritoneal mass with three connecting compartments. The patient was studied at baseline and at 1,8 , and 15 weeks with ${ }^{18}$ F-FLT. FLT-uptakes decreased in the most active site as follows: SUVmax $5.8 \rightarrow 4.2(-28 \%) \rightarrow 3.5(-40 \%)$. The biggest tumor actually increased in size on CT as follows: $4.1 \mathrm{~cm} \times 3.2 \mathrm{~cm} \rightarrow 5.5 \mathrm{~cm} \times 4.1 \mathrm{~cm} \rightarrow 5.6 \mathrm{~cm} \times 5.2 \mathrm{~cm}$ (Figure 2).

Next, 10 patients who were treated with c-met inhibitor ( 5 patients) or -2 inhibitor ( 5 patients) and had a total of 11 lesions were studied for early response with FLT (Table 2). They were studied at baseline and once after the initiation of the new therapy at 1-4 weeks. Five patients demonstrated FLT response, three patients had no change, and two patients progressed. Among these patients, two anecdotal patient cases are detailed in the figures. A patient with clear cell sarcoma of the left foot was studied at baseline and at one week with ${ }^{18} \mathrm{~F}-\mathrm{FLT}$ and with ${ }^{18} \mathrm{~F}-\mathrm{FDG}$ (Figure 3). This patient had a sub-carinal lymph node metastasis. With ${ }^{18} \mathrm{~F}-\mathrm{FLT}$, the outcome at one week was $-13 \%(\mathrm{R})$, whereas ${ }^{18} \mathrm{~F}-\mathrm{FDG}$ did not show any response $+37 \%$, and SUVmax increased from 8.9 to 12.2 . On CT scans, the tumor was slightly larger: $2.2 \mathrm{~cm} \times 1.2 \mathrm{~cm} \rightarrow 2.3 \mathrm{~cm} \times 1.5 \mathrm{~cm}$ (Figure 3). In Figure 4, a patient with a fibrous tumor in pleura is shown, demonstrating a right lung mass. The patient was studied at baseline and at 1 week with ${ }^{18} \mathrm{~F}-\mathrm{FLT}$ and the concentration decreased $-43 \%$. On CT, the tumor was slightly larger: $2.4 \mathrm{~cm} \times 1.9 \mathrm{~cm} \rightarrow 2.5 \mathrm{~cm} \times 2.0 \mathrm{~cm}$ (Figure 4). 


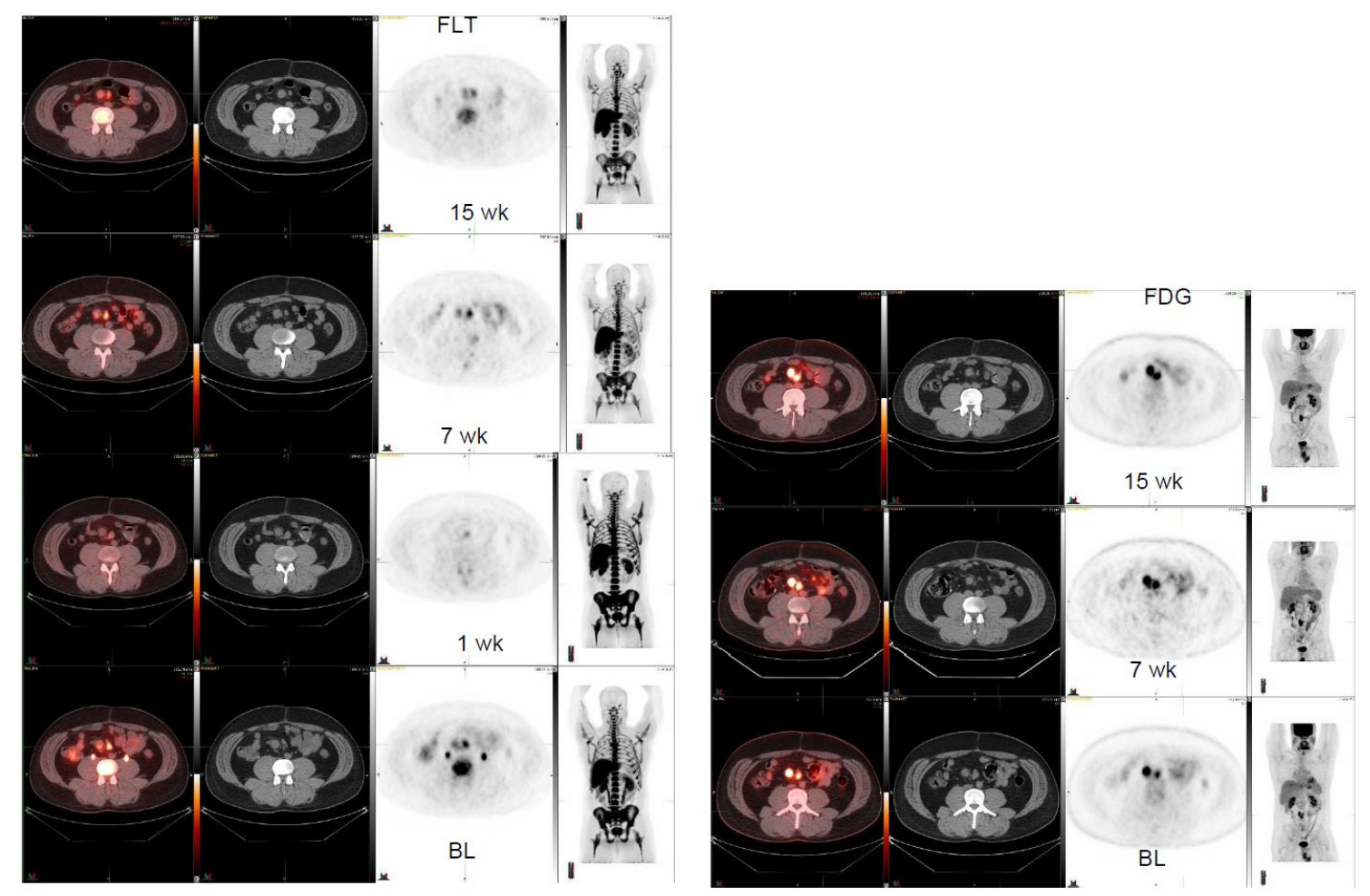

Figure 1. Gastro neuroectodermal tumor (GNET). FLT-study at baseline, at 1, at 7, and at 15 weeks (left panel, 4 rows). In the right mesenteric lymph node, FLT varies: SUVmax 5.2 ->3.2 -> 3.9 ->2.8 whereas corresponding sizes change on CT as follows: $2.2 \mathrm{~cm} \times 1.9 \mathrm{~cm}->2.0 \mathrm{~cm} \times 1.8 \mathrm{~cm}->2.0 \mathrm{~cm} \times$ $2.0 \mathrm{~cm}->1.9 \mathrm{~cm} \times 1.7 \mathrm{~cm}$. In the left mesenteric lnn, FLT varies: SUVmax $5.5->3.4->5.9->4.0$ whereas corresponding sizes change on CT as follows: $2.3 \mathrm{~cm} \times 1.6 \mathrm{~cm}->1.9 \mathrm{~cm} \times 1.5 \mathrm{~cm}->2.1 \mathrm{~cm} \times 1.4 \mathrm{~cm}$ $->2.0 \mathrm{~cm} \times 1.2 \mathrm{~cm}$. FDG-study at baseline, at 7, and at 15 weeks (right panel, 3 rows). In the right mesenteric lnn, FDG varies: SUVmax 12.9 ->nm -> 15.4->10.6 and in the left mesenteric lnn: SUVmax 8.2 ->nm $->9.9->8.0$.

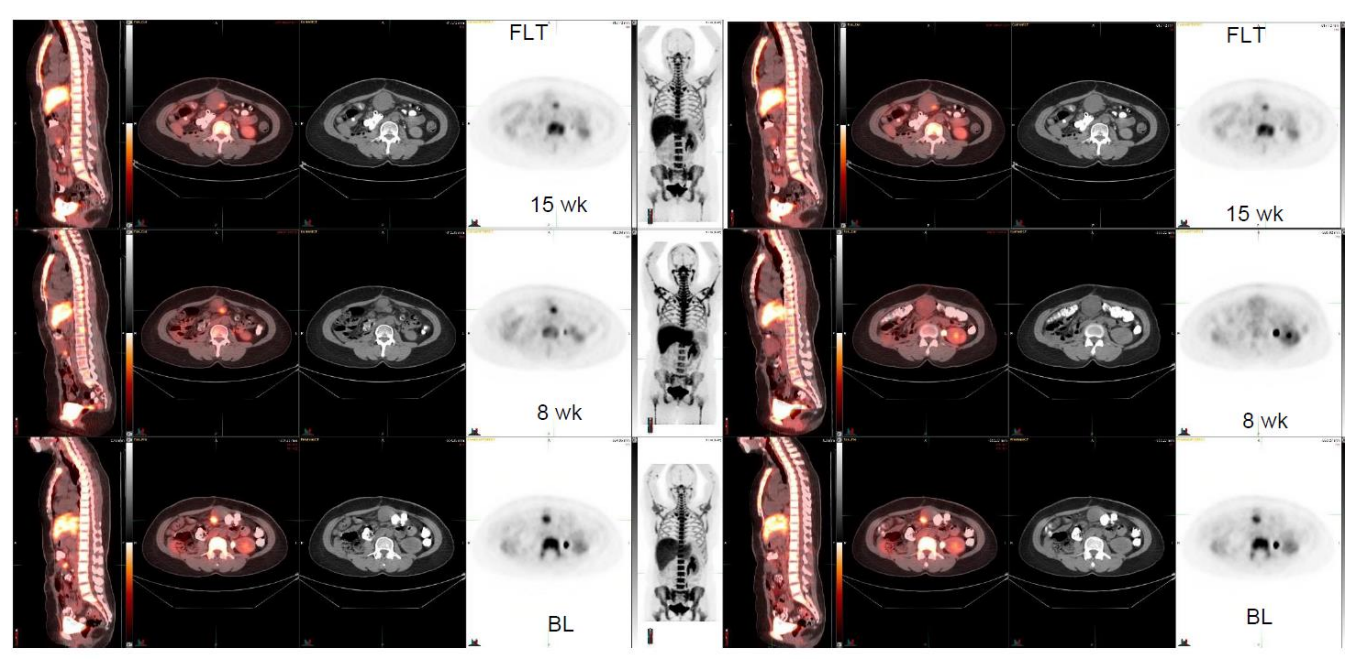

Figure 2. Liposarcoma. FLT-study at baseline, at 8, and at 15 weeks ( 3 rows). Anterior peritoneal mass is seen; the tumor consists of three components, which are in connection. The biggest tumor changes on CT as follows: $4.1 \mathrm{~cm} \times 3.2 \mathrm{~cm} \rightarrow>5.5 \mathrm{~cm} \times 4.1 \mathrm{~cm}->5.6 \mathrm{~cm} \times 5.2 \mathrm{~cm}$. FLT-uptakes changes in the most active site as follows: SUVmax $5.8->4.2->3.5$. 


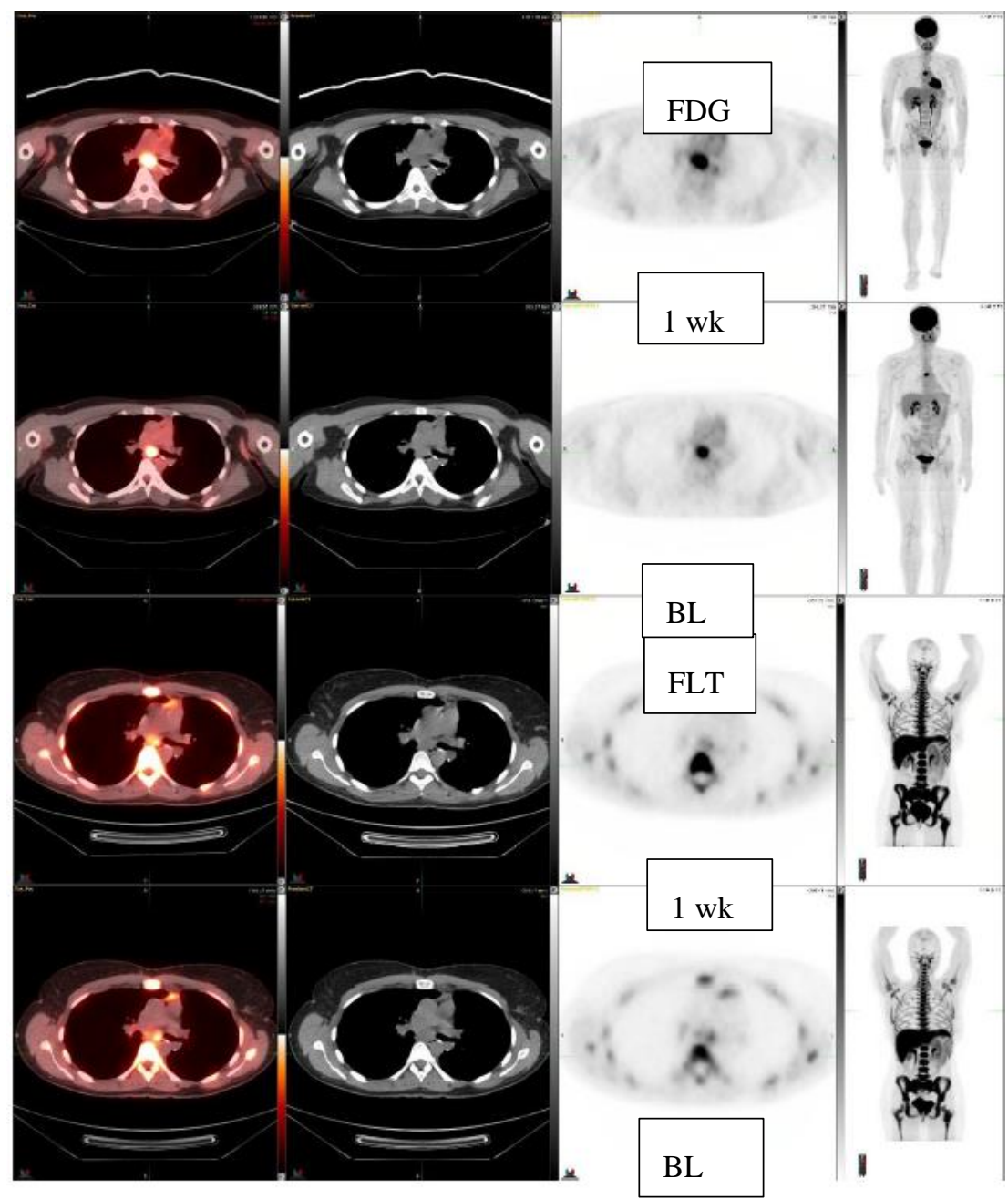

Figure 3. Clear cell sarcoma, left foot, lung resection. FDG-study at baseline and at 1 week (2 upper rows). FLT-study at baseline and at 1 week (2 lower rows). FDG-uptake increases $37 \%$ in a subcarinal lymph node: SUVmax 8.9 ->12.2, whereas FLT-uptake decreases 13\%, FLT: SUVmax 3.0 ->2.6. On CT it becomes slightly bigger, CT: $2.2 \mathrm{~cm} \times 1.2 \mathrm{~cm}->2.3 \mathrm{~cm} \times 1.5 \mathrm{~cm}$.

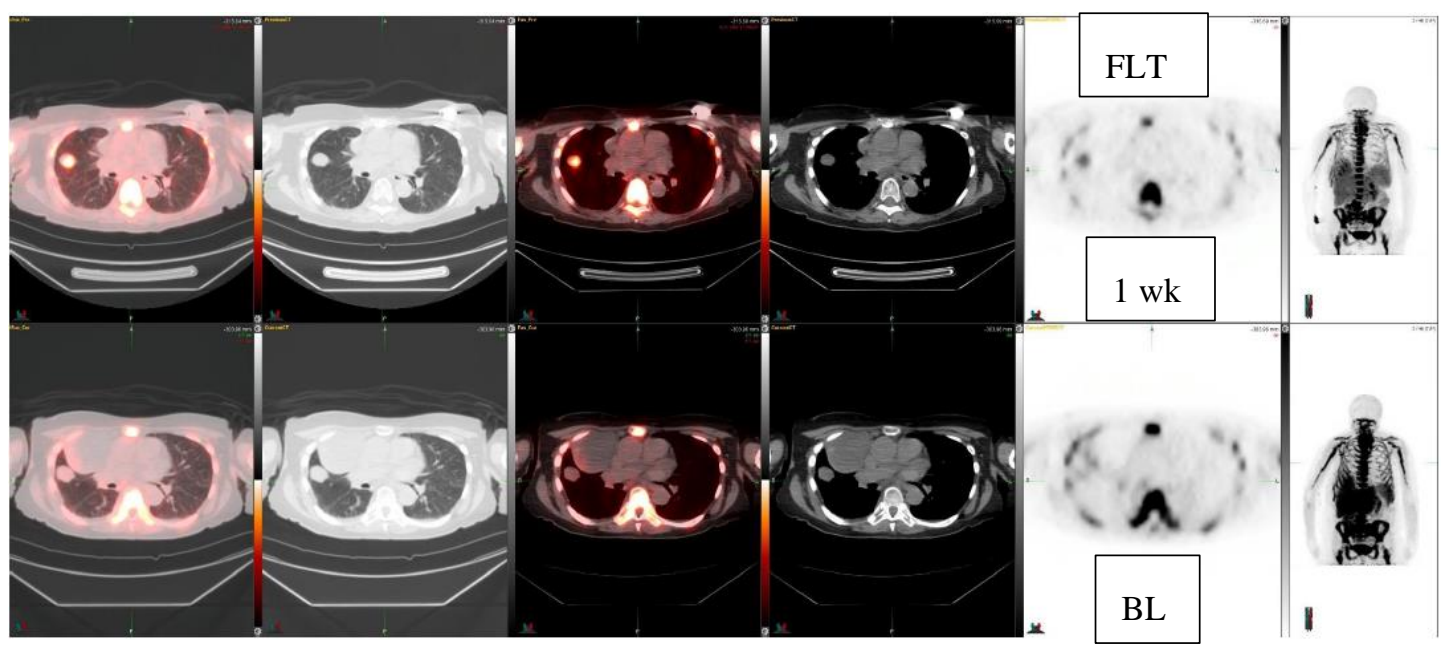

Figure 4. Fibrous tumor, pleura. FLT-study at baseline and at 1 week ( 2 rows) demonstrates decrease $(-43 \%)$ in the lung mass: FLT: SUVmax $3.0->1.7$. On CT it becomes slightly bigger, CT: $2.4 \mathrm{~cm} \times 1.9 \mathrm{~cm}$ $->2.5 \mathrm{~cm} \times 2.0 \mathrm{~cm}$. 


\section{Discussion}

The utility of ${ }^{18} \mathrm{~F}-\mathrm{FLT}$ in the evaluation of early treatment response in patients with sarcomas is largely unknown, even though several anecdotal non-clinical [13-17] and clinical experience in case reports exist [18]. This is a preliminary report of using ${ }^{18}$ F-FLT-CT in the assessment of response/ early signals of activity for two novel targeted therapies in multiple types of sarcomas.

Sarcomas are very heterogeneous tumors. It has already been shown that diagnosis and staging can be performed in small populations both by using ${ }^{18}$ F-FLT and ${ }^{18}$ F-FDG $[2,8-10]$. Grading between low grade and high grade is also possible with both tracers. In one study [10], mean FLT-SUV in benign lesions was 0.7 (range 0.3-1.3), and 1.3 in low-grade sarcoma (grade1; range 1.0-1.6), 4.1 (range, $2.2-6.0 ; p=0.002$ ) and 6.1 (range, 2.5-8.3; $p=0.001$ ) in grade 2 and grade 3 tumors, respectively. FLT but not FDG uptake correlated significantly with tumor grading ( $r=0.71$ versus $r=0.01)$ [10], and a cutoff value of 2.0 for FLT-SUV discriminated between low- and high-grade tumors. All the tumors in Table 1 were high-grade sarcomas according to the FLT classification and these were imaged three times. The tumors in Table 2 vary from grade 1 to grade 3.

The cut off-value for significant FLT-change has not been discussed in the assessment of early response, because there are no earlier studies nor published criteria. In Figure 3, the decrease of 13\% can be seen clearly. The change of $10 \%$ being significant is based on our own experience in this material where the highest baseline value was 8.8 and lowest 0.7 , respectively. Thus, the $10 \%$ change would correspond to SUV changes more than $0.1-0.9$ in these patients, which even can be visually observed. There might be a dynamic factor, but 10 of the 15 patients were studied at $1-4$ weeks. Typically, PET response is evaluated at 2-3 months. In our case series of only five patients studied for more than three times should be viewed a preliminary. This does not enable further inferences for dynamic behavior of FLT in the early response assessment.

Because thymidine is a DNA base, not found in RNA, which can be labelled with fluorine without essentially changing thymidine kinetics, it acts as a surrogate for DNA synthesis and cellular proliferation. After an intravenous injection, FLT crosses cell membranes and enters tissues by nucleoside transporters, which influence uptake in tumors [4]. This FLT uptake is proportional to cellular proliferation in tumors, whereas glucose uptake is regulated by glut-1 transporter and characterized by glucose consumption.

Here, we have shown that multiple sarcoma subtypes can be imaged using FLT (Figures 1-4. Figure 1 demonstrates that FDG uptake increases early, whereas FLT remains stable or decreases. The FDG uptake may also demonstrate pseudoprogression, which is typical for immunotherapies. Similarly, in Figure 3, the FLT uptake decreases and FDG uptake increases. We also see that the decrease in cell proliferation can be imaged using FLT in spite of the SUV level (Figures 1-4).

Although this a small study, we show that FLT may be used to predict responses to c-MET inhibitor or MDM2 inhibitor in diverse sarcoma sub-types. In spite of a very heterogeneous population, we have been able to demonstrate early response in seven out of eight patients who responded according to early response criteria. Early progression based on FLT increase more than $10 \%$ was seen in four out of four patients who progressed (Tables 1 and 2). Early FDG uptake increased in three patients studied at the same time, whereas the FLT uptake decreased. This should be considered as anecdotal, because FDG was not planned for comparison. Additionally, subtle changes and intra-tumor dynamics that may not be readily evaluable in conventional CT scans can be visualized with FLT PETs. Although RECIST responses are used in sarcomas in clinical trials, they have their shortcomings in sarcoma and may also be challenging to interpret (Tables 1 and 2). Many sarcomas do not shrink when they respond to systemic therapy, especially targeted therapy. Several other criteria have been evaluated in sarcoma to assess response or lack of response to therapies.

FLT PET should always be used as a follow-up of a new therapy for comparison with baseline. A single study may be beneficial only for staging of aggressive tumors with high uptakes. We also observed that intra- and intertumoral heterogeneity could be visualized using FLT, such as in Figure 2 . There is a trend of sex difference showing that females' response is more pronounced than males. 
However, given the heterogeneity of the tumors, heterogeneity of therapy, different therapies in different dose levels, low number of patients, and the power, it may be premature to make observations or any conclusions based on this data.

In this pilot study, proliferative early response was assessed by ${ }^{18}$ F-FLT-PET scans at baseline and during the course of the trial of c-met inhibitors and mdm2 -inhibitors. Especially, for the 10 patients who were imaged early, all the studies were carried out up to four weeks after initiation of the therapy. The additional five patients, who were assessed in at least three time points up to 15 weeks, were also assessed early. Earlier FLT has been assessed only after completing neoadjuvant therapy. A pilot study by Benz et al., which also studied tissue thymidine kinase 1(TK1) and Ki-67, did not find any correlation between FLT uptake and TK1 nor with Ki-67 [8]. It turned out to be of limited value in the assessment of response; in their 20 patients, 3 responded to neoadjuvant therapy, i.e., mostly chemoradiotherapy or chemotherapy (15 patients totally), whereas targeted therapy was given only to three patients and two patients got radiation only [8].

Here, we tested the use of early FLT in two forms of targeted therapy. In our 15 patient study, change in the FLT behavior was observed in 12 patients, 8 patients demonstrated response, and 4 progressed, meaning that $80 \%$ of the patients had new complementary information. There was no change in three patients $(20 \%)$.

Our study demonstrates that in spite of its heterogeneity and challenges in early diagnostics, FLT may be relevant in the assessment of new targeted therapies in sarcomas.

Author Contributions: Conceptualization, K.K., E.B.S., H.A.M. and V.S.; methodology, K.K., E.B.S.; validation, K.K., E.B.S.; formal analysis, K.K., E.B.S.; investigation, K.K., E.B.S.; resources, all authors; data curation, K.K., E.B.S.; writing—original draft preparation, K.K., E.B.S.; writing-review and editing, All authors; visualization, K.K.; supervision, H.A.M., V.S.; project administration, All authors. All authors have read and agreed to the published version of the manuscript.

Funding: The MD Anderson Cancer Center Support Grant (P30 CA016672). The funders had no role in the design of the study; the collection, analysis, and interpretation of the data; the writing of the manuscript; and the decision to submit the manuscript for publication.

Conflicts of Interest: K.K. reports no COI. V.S. reports the following conflicts of interest: Research funding/ Grant support for clinical trials: Roche/Genentech, Novartis, Bayer, GlaxoSmithKline, Nanocarrier, Vegenics, Celgene, Northwest Biotherapeutics, Berghealth, Incyte, Fujifilm, Pharmamar, D3, Pfizer, Multivir, Amgen, Abbvie, Alfa-sigma, Agensys, Boston Biomedical, Idera Pharma, Inhibrx, Exelixis, Blueprint medicines, Loxo oncology, Medimmune, Altum, Dragonfly therapeutics, Takeda and, National Comprehensive Cancer Network, NCI-CTEP and UT MD Anderson Cancer Center, Turning point therapeutics, Boston Pharmaceuticals. Travel: Novartis, Pharmamar, ASCO, ESMO, Helsinn, Incyte. Consultancy/ Advisory board: Helsinn, LOXO Oncology/ Eli Lilly, R-Pharma US, INCYTE, QED pharma, Medimmune, Novartis.Other: Medscape.

\section{References}

1. Buck, A.K.; Bommer, M.; Stilgenbauer, S.; Juweid, M.; Glatting, G.; Schirrmeister, H.; Mattfeldt, T.; Tepsic, D.; Bunjes, D.; Mottaghy, F.M.; et al. Molecular Imaging of Proliferation in Malignant Lymphoma. Cancer Res. 2006, 66, 11055-11061. [CrossRef] [PubMed]

2. Been, L.B.; Suurmeijer, A.J.H.; Elsinga, P.H.; Jager, P.L.; Van Ginkel, R.J.; Hoekstra, H.J. 18F-fluorodeoxythymidine PET for evaluating the response to hyperthermic isolated limb perfusion for locally advanced soft-tissue sarcomas. J. Nucl. Med. 2007, 48, 367-372. [PubMed]

3. Kairemo, K.; Ravizzini, G.; Macapinlac, H.; Subbiah, V. An Assessment of Early Response to Targeted Therapy via Molecular Imaging: A Pilot Study of 3'-deoxy-3'[(18)F]-Fluorothymidine Positron Emission Tomography 18F-FLT PET/CT in Prostate Adenocarcinoma. Diagnostics 2017, 7, 20. [CrossRef] [PubMed]

4. Shields, A.F.; Grierson, J.R.; Dohmen, B.M.; Machulla, H.-J.; Stayanoff, J.C.; Lawhorn-Crews, J.M.; Obradovich, J.E.; Muzik, O.; Mangner, T.J. Imaging proliferation in vivo with [F-18]FLT and positron emission tomography. Nat. Med. 1998, 4, 1334-1336. [CrossRef] [PubMed]

5. Nimmagadda, S.; Shields, A.F. The role of DNA synthesis imaging in cancer in the era of targeted therapeutics. Cancer Metastasis Rev. 2008, 27, 575-587. [CrossRef] [PubMed] 
6. Aoki, J.; Watanabe, H.; Shinozaki, T.; Takagishi, K.; Ishijima, H.; Oya, N.; Sato, N.; Inoue, T.; Endo, K. FDG PET of Primary Benign and Malignant Bone Tumors: Standardized Uptake Value in 52 Lesions. Radiology 2001, 219, 774-777. [CrossRef]

7. Shreve, P.D.; Anzai, Y.; Wahl, R.L. Pitfalls in Oncologic Diagnosis with FDG PET Imaging: Physiologic and Benign Variants. Radiographics 1999, 19, 61-77. [CrossRef] [PubMed]

8. Benz, M.R.; Czernin, J.; Allen-Auerbach, M.S.; Dry, S.M.; Sutthiruangwrong, P.; Spick, C.; Radu, C.; Weber, W.A.; Tap, W.D.; Eilber, F.C.; et al. 3'-deoxy-3'-[18F]fluorothymidine positron emission tomography for response assessment in soft tissue sarcoma: A pilot study to correlate imaging findings with tissue thymidine kinase 1 and Ki-67 activity and histopathologic response. Cancer 2012, 118, 3135-3144. [CrossRef] [PubMed]

9. Cobben, D.C.P.; Elsinga, P.H.; Suurmeijer, A.J.H.; Vaalburg, W.; Maas, B.; Jager, P.L.; Hoekstra, H.J. Detection and grading of soft tissue sarcomas of the extremities with (18)F-3'-fluoro-3'-deoxy-L-thymidine. Clin. Cancer Res. 2004, 10, 1685-1690. [CrossRef] [PubMed]

10. Buck, A.K.; Herrmann, K.; Buschenfelde, C.M.Z.; Juweid, M.E.; Bischoff, M.; Glatting, G.; Weirich, G.; Möller, P.; Wester, H.-J.; Scheidhauer, K.; et al. Imaging Bone and Soft Tissue Tumors with the Proliferation Marker [18F]Fluorodeoxythymidine. Clin. Cancer Res. 2008, 14, 2970-2977. [CrossRef] [PubMed]

11. Moumen, A.; Patanè, S.; Porras, A.; Dono, R.; Maina, F. Met acts on Mdm2 via mTOR to signal cell survival during development. Development 2007, 134, 1443-1451. [CrossRef] [PubMed]

12. Machulla, H.-J.; Blocher, A.; Kuntzsch, M.; Piert, M.; Wei, R.; Grierson, J. Simplified Labeling Approach for Synthesizing 3'-Deoxy-3'-[18F]fluorothymidine ([18F]FLT). J. Radioanal. Nucl. Chem. 2000, 243, 843-846. [CrossRef]

13. Li, Z.; Herrmann, K.; Pirsig, S.; Philipp-Abbrederis, K.; Henninger, M.; Aichler, M.; Feuchtinger, A.; Walch, A.; Beer, A.J.; Ringshausen, I.; et al. Molecular imaging for early prediction of response to Sorafenib treatment in sarcoma. Am. J. Nucl. Med. Mol. Imaging 2013, 4, 70-79. [PubMed]

14. Karroum, O.; Mignion, L.; Kengen, J.; Karmani, L.; Leveque, P.; Danhier, P.; Magat, J.; Bol, A.; LaBar, D.; Gregoire, V.; et al. Multimodal imaging of tumor response to sorafenib combined with radiation therapy: Comparison between diffusion-weighted MRI, choline spectroscopy and18F-FLT PET imaging. Contrast Media Mol. Imaging 2013, 8, 274-280. [CrossRef] [PubMed]

15. Perumal, M.; Pillai, R.G.; Barthel, H.; Leyton, J.; Latigo, J.R.; Forster, M.; Mitchell, F.; Jackman, A.L.; Aboagye, E.; Wang, Z.; et al. Redistribution of Nucleoside Transporters to the Cell Membrane Provides a Novel Approach for Imaging Thymidylate Synthase Inhibition by Positron Emission Tomography. Cancer Res. 2006, 66, 8558-8564. [CrossRef] [PubMed]

16. Leyton, J. Early Detection of Tumor Response to Chemotherapy by 3'-Deoxy-3'-[18F]Fluorothymidine Positron Emission Tomography: The Effect of Cisplatin on a Fibrosarcoma Tumor Model In vivo. Cancer Res. 2005, 65, 4202-4210. [CrossRef] [PubMed]

17. Osgood, C.L.; Tantawy, M.N.; Maloney, N.; Madaj, Z.B.; Peck, A.; Boguslawski, E.; Jess, J.; Buck, J.; Winn, M.E.; Manning, H.C.; et al. 18F-FLT Positron Emission Tomography (PET) is a Pharmacodynamic Marker for EWS-FLI1 Activity and Ewing Sarcoma. Sci. Rep. 2016, 6, 33926. [CrossRef] [PubMed]

18. Kairemo, K.; Subbiah, V. Molecular imaging of metastatic atrial angiosarcoma with positron emission tomography (PET) tracer $3^{\prime}$-deoxy-3'[(18)F]-fluorothymidine, [(18)F]-FLT imaging and early response evaluation. BMJ Case Rep. 2019, 12, e218979. [CrossRef] [PubMed]

(C) 2020 by the authors. Licensee MDPI, Basel, Switzerland. This article is an open access article distributed under the terms and conditions of the Creative Commons Attribution (CC BY) license (http://creativecommons.org/licenses/by/4.0/). 